\title{
THE LAW OF IMPEACHMENT IN THE UNITED STATES
}

DAVID Y. THOMAS

University of Arkansas

When the Fathers were framing the Constitution of the United States they sought at every turn to safeguard the interests of the people and at the same time secure to officials a reasonable degree of independence. This solicitude was especially manifest in the case of judicial officers, whose terms were made to run during good behavior. Impeachment was the method adopted to determine what constituted misbehavior. Chief Justice Marshall early laid down the principle that terms otherwise undefined in the Constitution were used in the sense which was well known and accepted at the time the Constitution was written. ${ }^{1}$ Impeachment was adopted and adapted from the English practice. To understand our own law, then, it is necessary to know what the English law of impeachment, the lex et consuetudo parliamenti, was at the time of its adoption and in what way it was modified or changed in being adopted.

"Impeachment" was a term as well known as "felony" or "levying war.". It was a sort of political trial, generally used to reach offenders who might have escaped indictment at the common law. It was designed both to protect the state and to punish the offender. The custom was for the commons to make accusation at the bar of the lords, who were judges of the law and facts and fixed the penalty. All the king's subjects were liable to impeachment, whether officials or not, and for any offense. Another method of punishment closely allied to that of impeachment was that of attainder, wherein the parliament made the law and fixed the penalty to suit the case before them.

In adopting impeachment the Americans did so with certain modifications. In the first place it is to be noted that they rejected attainders outright. They also limited the offenses for which one could be im-

${ }^{1}$ Burr Trial, quoted in Swayne Trial, 376. 
peached to treason, bribery, or other high crimes and misdemeanors. This was felt to be necessary because the commons had sometimes impeached for trivial offenses. Treason is defined in the Constitution. The other impeachable crimes and offenses are not and for their definition recourse must be had to the common law. This seems to be universally admitted, though, to be consistent, it would seem that those who deny a common law jurisdiction to the United States would also have to deny the use of the common law for purposes of definition. Bribery is a term so well known that it needs no discussion. High crimes and misdemeanors is a term less definite, but it is generally used to cover offenses not given a particular name by law. Such offenses may arise from a violation of either common or statute law. Our supreme court early held that the United States courts have no common law jurisdiction (a decision which has not been rigidly followed), but at the time of writing his Commentaries Mr. Justice Story said: "However much it may fall in with the political theories of certain statesmen and jurists to deny the existence of a common law belonging to and applicable to the nation in ordinary cases, no one has yet been bold enough to assert that the power of impeachment is limited to offenses defined in the statute book of the Union as impeachable high crimes and misdemeanors." 2 Mr. G. T. Curtis even went so far as to say that officials were impeachable "where no offense against positive law has been committed." 3 In the Johnson trial, however, Mr. B. R. Curtis, one of the counsel for the defendant, seems to have been of opinion that, to be impeachable, a high crime or misdemeanor must arise from a violation of a statute of the United States. ${ }^{4}$ A sufficient answer to this may be found in the statement that such was not the law in England, that the English law of impeachment was adopted entire, except wherein it was changed by our Constitution, and that there is nothing in the Constitution which changes the law in this respect. It is not held that the common law may be resorted to for a jurisdiction not given by the Constitution or laws; but, when a jurisdiction is given, as it is in impeachments, it is to be exercised according to the principles of the common law. In our first four

${ }^{2}$ Commentaries on the Constitution of the United States, sec. 797.

${ }^{3}$ History of the Constitution of the Unied States, ii, $260 \mathrm{f}$.

4 Johnson Trial (Supp. to Globe, 40 Cong., 2 Sess.), 134. 
trials not a single charge rested upon a statutable offense and the same was true of some of the articles in most of the other trials.

A question closely related to this is whether the crime must be committed in the discharge of official duties. Messrs. Higgins and Thurston, counsel for the respondent in the Swayne trial, endeavored to draw a distinction between judicial and political offenders, holding that the former were impeachable only for crimes committed in the performance of official duties, but, by implication at least, that this was not true of the latter. This novel conclusion was reached by an examination of English and American precedents, which, according to the defense, show that impeachment accusations against judges have been limited, "with the greatest strictness, to the acts of judgment performed by the judge on the bench." 'The defense admit that bribery is an exception. ${ }^{5}$ Dr. Hannis Taylor, evidently the author of the argument for the defendant in the Swayne trial, the authorship of which was disavowed by Higgins and Thurston, also excepts treason. In a sentence which begs the whole question, he says that, previous to the Swayne trial, the "house of representatives, in drafting its articles, adhered with the greatest strictness to the English rule, which provides that the judicial acts [italics ours] constituting high crimes and misdemeanors must be committed by the judge, on the bench, while in the actual administration of justice." In support of this statement he says that, previous to the Swayne trial, all charges against American judges were for judicial misconduct, except in the case of Humphreys, who was charged with treason, and "then, strangely enough, he was charged with judicial misconduct while sitting on the bench of a court of the Confederate States." A fact which the distinguished publicist thinks adds peculiar force to his contention. ${ }^{6}$

The writer would like to know how "judicial acts constituting high crimes and misdemeanors" or any other kind of judicial acts can be committed anywhere except on the bench, unless an attempt to administer justice "in vacation" be considered an attempt to do so off the bench. Nor is it clear that such an English rule as that quoted above has ever been established. If so, and judges are impeachable only under that rule, the whole question is settled. The rule is deduced by

${ }^{5}$ Swayne Trial (S. Doc. 194, 58 Cong., 2 Sess.), 385, 389.

- The American Law of Impeachment, Norih American Review, vol. 180, p. $510 f$. 
the writers referred to from the history of judicial impeachments in England, which, it seems, does not show that any judge was ever actually impeached except for judicial misconduct.

But the whole case is given away by the defense in the Swayne trial. "Excepting bribery," they say, "there is no case in the parliamentary law of England which gives color to the idea that the personal misconduct of a judge, in matters ouside of his administration of the law in a court of justice, was ever considered or charged to constitute a high crime and misdemeanor. When the question is asked by what means is the personal misconduct of an English judge, not amounting to a high crime and misdemeanor, punished, the answer is easy." And the answer is by address of both houses of parliament since the passage of the act of settlement in $1701 .^{7}$ But it is not shown that this act forbids impeachment of judges for other than official conduct. The truth seems to be that it simply provides a more summary way of removal than that of impeachment since their commissions run during good behavior. Six State constitutions, five of which were adopted before the Federal Constitution, are then quoted to show that these States adopted this view, since they provided for removal both by impeachment, and by address "for any reasonable cause which shall not be a sufficient ground for impeachment." Now if this means anything, it simply means that these States adopted the two English methods of determining "good behavior," which was the tenure adopted for the judges. Then, as if utterly to destroy their case, Messrs. Higgins and Thurston quoted the debates in the convention of 1787 to show that that body expressly and purposely adopted one method, that of impeachment, and rejected the other, that of address. Since they at the same time adopted the tenure of good behavior, it would be strange indeed if they purposely crippled themselves in determining what was not good behavior. The constitution of New York, said to have been the model on this subject in the convention of 1787 , omits removal on address. All of which goes to show that impeachment was considered a sufficient means for determining good behavior and that

\footnotetext{
${ }^{7}$ Swayne Trial, 385. The evidence that Dr. Hannis Taylor is responsible for all of these ideas consists in the fact that, in his North American Review article, he uses several excerpts from the argument of the defense in the Swayne trial without using quotation marks or giving anybody credit for them.
} 
removal on address was believed to be too summary and likely to become an instrument of party vengeance. Surely no one will assert that the members of the convention of 1787 would have maintained that any man who was guilty of high crimes and misdemeanors not connected with the discharge of his official duties was fit to administer the affairs of state.

It has been urged that the ordinary courts can deal with such offenders. So can they deal with treason and bribery, both of which are admitted to be impeachable offenses when not committed in the discharge of official duties. Why this difference? Besides, there is a highly practical side to the question. Suppose that a federal judge has been convicted in a State court and confined to the penitentiary: his office is not thereby vacated, a fact to which Mr. Dallas called attention in the Blount trial. ${ }^{8}$ We are then reduced to the absurdity, reductio ad horribile as Dr. Taylor would call it, of supposing that he must be allowed to continue in office, though it is impossible for him to perform the duties thereof. Instead, however, of revealing an omission in our Constitution, as Dr. Taylor holds, this only shows that the convention considered impeachment a sufficient means of reaching treason, bribery, or other high crimes and misdemeanors, whether committed in the discharge of official duties or not.

Such seems to have been the interpretation put upon the power of impeachment since the adoption of the Constitution, without distinction between political and judicial officers, though at times certain persons in whose interest it was to do so have denied it. In the Blount trial Messrs. Dallas and Ingersoll, counsel for the defendant, entered the plea that their client had not committed the offenses charged in connection with his duties as a senator and that crimes not committed in an official capacity were not impeachable. ${ }^{9}$ In support of this they quoted several State constitutions, among them those of New York and Massachusetts, which expressly limited impeachable crimes to those committed in the performance of official duties. Again it may be observed that this is negative proof of the impeachability of other than official crimes, since the convention, in following the constitution of New York, omitted this feature of it. Messrs. Bayard and Harper,

${ }^{8}$ Ann. 5 Cong., 2267.

'Ibid., 2247, 2282, 2287f. 
managers for the house, ably maintained that impeachment was not limited to official acts. ${ }^{10}$ The senate cannot be said to have decided one way or the other on this point. Two of our ablest commentators have sided with Bayard and Harper. ${ }^{11}$

The next three impeachments, those of Pickering, Chase, and Peck, were judicial, and in each case the accused was charged only with official crimes. In 1862 seven articles of impeachment were presented against Judge West H. Humphreys, of Tennessee, not one of which charged him with misconduct on the bench, though one, and only one, did charge him with official misconduct in refusing to hold court. Several of the articles charged him with advocating secession in a public speech, levying war against the United States and with certain things done while sitting in an illegal tribunal "called the district court of the Confederate States," but it would be absurd to say that such acts were official crimes. They fall either under the head of treason or of high crimes and misdemeanors, ${ }^{12}$ not one of which, except treason, was indictable. One of the articles against Andrew Johnson, the tenth, which charged him with a high crime and misdemeanor because of speeches denouncing the Republican majority in congress, had nothing whatever to do with his official conduct, except in so far as he was "unmindful of the high duties of his office and of the dignity and proprieties thereof." In 1873 the house of representatives began proceedings against Judge Busteed, of Alabama, with a view to impeachment for not residing within his district. When the committee of investigation reported that the only evidence he had of residence in the State consisted in "a carpet, a music box, and a double-barreled gun," the judge resigned and the proceedings were dropped. ${ }^{13} \mathrm{Wm} . \mathrm{W}$. Belknap, secretary of war in 1876, was impeached for corruption in office. The next case was that of Judge Swayne, 1904-05. In this the managers, following the English and American precedents, did not confine themselves to official misconduct, but charged him with certain high crimes and misdemeanors which had no connection with the administration of justice.

${ }^{10}$ Ibid., 2261, 2300.

${ }^{11}$ Curtis, History Constitution, ii, 260f.; Story, Commentaries, sec. 804.

12 Extracts from the Journal of the Senate in Cases of Impeachments (Washington, 1904), $183 f f$.

${ }^{13}$ Swayne Trial, $605 f$. 
Nothing is to be gained by an examination of impeachments that have occurred in the commonwealths and showing that they were for mal-administration. Several such trials have occurred in Massachuetts, New York, Pennsylvania, North Carolina, and Mississippi, but in each of these States impeachment was expressly limited to official misconduct. ${ }^{14}$

Nor can anything be gained by resorting to the antiquated doctrine of strict construction and holding that, since the power to impeach for crimes committed out of an official capacity has not been expressly conferred, it must be denied. It is only necessary to point out once more that the whole English law of impeachment was adopted except in so far as it was modified in the Constitution. The fact that removal on address was rejected in the convention, as also the express provision limiting impeachments to crimes committed in an official character, is only added proof that there was no intention to make such a limitation in the Constitution. Something more than negative proof on the English law is needed to convince that judges are not impeachable except for official high crimes and misdemeanors. No distinction is really made in the act of settlement between political and judicial offenders. To establish a difference in custom it is not sufficient to show that judges never have been impeached except for official miconduct; it must be shown that some cases occurred in which they were charged with high crimes and misdemeanors not committed in connection with their offices and that parliament expressly refused to impeach them. Until this is done the contention that American judges are not impeachable except for official misconduct cannot be regarded as established. It seems hardly so much as doubtful that English judges were impeachable for other than official crimes. In 1667 , the commons authorized their committee to "receive information against the Lord Chief Justice Keelying for any other misdemeanors besides those concerning juries." ${ }^{15}$ It may be that they had in mind only judicial misconduct, but the language is general. As already pointed out in the brief history of American impeachments, the power to try for other than official crimes has not been regarded as doubtful;

\footnotetext{
14 Johnson Trial, 49f.; Ann. 8 Cong. 1 Sess., 848; Garner, Reconsiruction in Mississippi, $401 \mathrm{ff}$.

${ }^{15}$ Ann. 8 Cong., 2 Sess., 648.
} 
or if doubtful, we have established a custom of our own. Without drawing any distinction between political and judicial impeachments, since there is none, out of eight trials, four were based upon charges of unofficial crimes. Out of five judicial trials, including that of Judge Swayne, two brought up unofficial crimes. Only two convictions have ever resulted, and in one of these Judge Humphreys was convicted on charges which had nothing to do with his official conduct.

An important question is, who may be impeached. The State constitutions adopted before the meeting of the federal convention show no uniformity on this point, but the most of them reveal an intention to limit the English law, according to which all the king's subjects were impeachable, whether in office or not, even if they had never held office. Pennsylvania provided that an officer might be impeached "either when in office or after his resignation." Delaware and Virginia would not allow the impeachment of the chief executive while in office and in the former all impeachments must be begun within eighteen months after the offense was committed, or in the case of the chief executive, within eighteen months after he left office. It is not expressly so stated, but the inference is that all officials of these two States were impeachable when out of office. Massachusetts, New Hampshire, and New York simply provided for the impeachment of officials with no hint as to whether they were subject to trial after resignation or the expiration of their terms. Nothing is said about private citizens, but as the constitutions made the State officials liable to impeachment and provided the means for their trial, saying nothing about private citizens who had never held office, the presumption is that they were not impeachable. But the constitution of Virginia was less specific. It said: "The governor, when he is out of office, and others offending against the State, either by maladministration, corruption, or other means, by which the safety of the State is endangered, shall be impeachable by the house of delegates." Certainly there is nothing here which changed the English law making private citizens impeachable. However, the penalties allowed imply that the impeached was an official. ${ }^{16}$

The Constitution of the United States provides for impeachments,

${ }^{16}$ These provisions may be found in Poore's Charters and Constitutions. 
but nowhere specifically names any class as liable to such trials. In the Blount trial Mr. Bayard, one of the managers, boldly maintained that even private citizens were impeachable and that they might be deprived of their political rights in this way before they ever held office. ${ }^{17}$ The contention seems to have made a deep impression at the time. The next day after Mr. Bayard's speech, Mr. Jefferson, the vicepresident, wrote to Mr. Madison: "I think that there will not be more than two votes north of the Potomac against the universality of the impeaching power." ${ }^{18}$ As Madison was so prominent in the formation of the Constitution his opinion is worthy of respect. In reply he said: "The universality of this power is the most extravagant novelty that has been broached." 19 The only clause which seems to limit this universality is that which says that "The President, Vice-President, and all civil officers of the United States shall be removed from office on impeachment for, and conviction of, treason, bribery, and other high crimes and misdemeanors." Another clause forbids judgment extending beyond removal from office and disqualification to hold office in the future. One disposed to a liberal interpretation might hold that private citizens were liable to impeachment and disqualification, but no one seems to have maintained this view since Bayard. It is now generally conceded that only officials are subject to impeachment.

A more important question is, when may the official be impeached. Since removal from office is made obligatory by the Constitution in case of conviction, some hold that, to be impeachable, the accused must be still in office. Such is the view of Story: "If, then, there must be a judgment of removal from office, it would seem to follow that the Constitution contemplated that the party was still in office at the time of impeachment. If he was not his offense was still liable to be tried and punished in the ordinary tribunals of justice. And it might be argued, with some force, that it would be a vain exercise of authority to try a delinquent for an impeachable offense, when the most important object for which the remedy was given was no longer necessary or attainable." 20

\footnotetext{
${ }^{17}$ Ann. 5 Cong., 2251, 2254.

${ }^{18}$ Quoted in the Belknap Trial (Cong., Rec., 44 Cong. 1 Sess., vol. 4, pt. 7), 157.

'o Ibid.

${ }^{20}$ Commentaries, sec. 804 .
} 
It is true that the most important object of impeachment is to remove the offender from office, but it may be very necessary to deprive him permanently of his political rights, which can be done only by impeachment. It is indeed "not so much designed to punish an offender as to secure the State," nevertheless it is a punishment. The disgrace attending such a condemnation certainly would weigh heavily upon any man. The offender may not have committed an indictable offense; shall he then be allowed to go scott free, if he vacates his office? It is also true that impeachment "touches neither his person nor his property," yet it is a proceeding directed against a person, not an officer as such. If a suit is brought against an officer to recover money illegally collected, it lies against him as a person when out of office as well as when in. His successor could not be touched for it. There certainly is some analogy between this and impeachments. Again, a man may have committed an indictable offense. Feeling that condemnation followed by the full penalty would be the result of impeachment, he might prefer to resign and suffer the penalties imposed in a court of law, trusting to the president or a State executive to remove his disabilities by pardon, a thing which cannot be done in cases of impeachment. In this way the whole object of impeachment could be defeated. A case in point is that of Belknap, where an upright president assisted in the defeat of an impeachment by accepting the resignation of the accused.

The history of the views on this question will be of interest. The question first arose in the Blount trial. In this case the house followed the strange course of accusing the senator of certain high crimes and misdemeanors and demanding at once that he be "sequestered from his seat," promising at the same time to present articles of impeachment at a later day. In response to this demand the senate expelled Blount with only one dissenting vote. ${ }^{21}$ When the articles were drawn up and Blount was ordered to appear, his counsel made answer by pleading to the jurisdiction of the senate on the ground that senators were not officers within the meaning of that term as used in the Constitution and that if they were, Blount was no longer subject to impeachment because no longer a senator. However, the defense expressly

${ }^{21}$ Ann. 5 Cong., 1 Sess., 39, 44. 
stated that they referred to vacation by expulsion. Said Mr. Ingersoll, one of the counsel for the defendant, "I certainly shall never contend that an officer may first commit an offense and afterwards avoid punishment by resigning his office." ${ }^{22}$

The senate cannot be said to have registered its opinion on this point in case of either voluntary or forced vacation. A resolution to the effect that Blount was an officer and therefore impeachable was negatived by a vote of 11 to 14 . The defendant's plea was then sustained by a vote of 14 to $11 .^{23}$ The most natural interpretation of this action is that the senate thought its members not impeachable. Jefferson predicted that such would be the decision. ${ }^{24}$ This view accords with the teachings of political science, in which the holding of legislative powers is called mandate.

During the progress of the Chase trial the defense labored to prove that only officers were impeachable, which really had nothing to do with the case, and this was cheerfully admitted by the managers. ${ }^{25}$ But it is not clear that they had ex-officials in mind. Rather they were thinking of private citizens as contrasted with officials.

Charges of corruption in office were brought against Daniel Webster in the house of representatives in 1846, though he had been out of office several years. The house then ordered the appointment of a committee to inquire into the charges "with a view of founding an impeachment against said Daniel Webster." Only one man, Mr. Bayley of Virginia, appears to have recorded any doubt at the time that ex-officials were impeachable. Said J. Q. Adams: "I hold, therefore, that *** every officer of the United States impeachable by the laws of the country is as liable twenty years after his office has expired as he is while he continues in office." ${ }^{26}$ The proceedings were dropped simply because the evidence did not warrant their continuance.

The charges against Judge Busteed, of Alabama, were dropped in 1873, apparently because the crime with which he was charged, that of violating the law requiring residence within his district, was not

\footnotetext{
${ }^{22}$ Ibid., 2278, 2293.

${ }^{23}$ Ibid., $2318 \mathrm{f}$.

${ }^{24}$ Quoted in Belknap Trial, 157.

${ }^{25}$ Ann. 8 Cong., 2 Sess., 594.

${ }^{26}$ Quoted in Belknap Trial, 151.
} 
serious enough to warrant impeachment after he had resigned. But in the Belknap trial the house and senate found themselves face to face with the question whether a man could escape impeachment by resigning. Wm. W. Belknap was secretary of war under President Grant in 1876. March 2 he realized that impeachment for corruption in office was certain and resigned about two hours before it was voted in the house, his resignation being immediately accepted by the president. But the house refused to consider their proceedings estopped thereby and voted to impeach without a division. At first the accused contented himself with pleading to the jurisdiction of the senate. His plea was simply that only officials were liable to impeachment and that he was not then, nor at the time the impeachment was voted, an officer of the United States. ${ }^{27}$

Nearly three months were consumed in the preparations for the trial and in the settlement of the question of jurisdiction. This question was argued ably and at length on both sides, after which the senate sustained the contention of the house by a vote of 37 to 29,7 not voting. The presiding officer ruled that the jurisdiction of the senate was sustained, but the respondent pleaded that it was not, since less than twothirds, the number necessary to convict, had voted yea, and begged that the case be dismissed. The issue thus raised came to a vote on a resolution to proceed with the trial as upon a plea of not guilty, if the accused failed to make answer, and the result was 21 yeas, 16 nays, 36 not voting. ${ }^{28}$

The trial then proceeded. For a while the counsel for the respondent refused to take any part in it, but finally decided to make some sort of a defense. In their final speeches, however, they still held that the senate had denied jurisdiction and that no senator who had so voted could now vote for condemnation without stultifying himself. Mr. Lynde argued the case well for the managers, pointing out the analogous practice of the courts, where any preliminary decision of the majority was binding upon the minority; that after a question of jurisdiction had been decided affirmatively, the minority were then bound to try the case on its merits. Orders of the senate were regularly passed by simple majority and were then binding upon all. A precedent in

${ }^{27}$ Ibid., pp. 111 and $6 \mathrm{f}$.

${ }^{28}$ Belknap Trial, 76, $173 f$. 
impeachments, that of Judge Barnard, was referred to, where nine men had voted against assuming jurisdiction on certain charges relating to a previous term, but after the jurisdiction was sustained had voted for condemnation. (However, jurisdiction was sustained by a two-thirds vote.) It may be objected that, while the supreme court decides all questions by simple majority vote, the senate can convict only by two-thirds, hence a similar vote is necessary to sustain jurisdiction. But Mr. Lynde pointed out that questions no less vital to the issue were decided by a simple majority; for example, in the Johnson trial evidence was admitted fifteen times when less than two-thirds had voted for its admission. ${ }^{28}$ Two senators who had voted against jurisdiction were convinced and answered "Guilty" on the question of guilt, but the rest refused to try the case on its merits and answered "Not guilty," giving as their reason for doing so, not the innocence of the accused, but their belief that the senate had no jurisdiction to try him. ${ }^{30}$

A few somewhat similar cases have occurred within the commonwealths. In 1796 the general assembly of North Carolina instituted impeachment proceedings against the secretary of state for corruption in office, whereupon he resigned and "superseded the necessity of an impeachment." The proceedings were then dropped and he was afterwards indicted at common law. ${ }^{{ }^{\star}}$ The constitution said nothing about the time when officers were liable to impeachment, as did some of the others, neither did it prescribe the penalty. In 1876 the legislature of Mississippi, which had been elected in the "Revolution" of the preceding year, began impeachments proceedings against several members of the carpet-bag government. The lieutenant-governor was impeached for bribery. "He attempted to resign, but the senate proceeded with the trial,"with conviction as the result. The governor and the superintendent of education were allowed to resign. Among the charges brought against the latter was one for misfeasance in office while clerk of the circuit court, an office which he no longer held. ${ }^{32}$ In 1893 the legislature of Nebraska in joint assembly impeached the attorney-

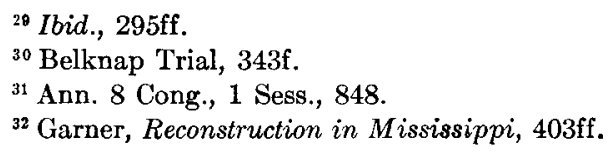


general before the supreme court, but that body dismissed the case, remarking that, since he was already out of office (by expiration of term), it was better that the State should be confined to the remedy afforded by the criminal code. ${ }^{33}$

Out of eight trials before the United States senate only two convictions have ever followed. In the first case Judge Pickering was simply removed from office; in the second Judge Humphreys was both removed and disqualified to hold office in the future. The first is a necessary incident of conviction; the second is discretionary. Since removal is made mandatory in the Constitution, it is at least doubtful if a formal vote is necessary to accomplish this result. There seems to be no reason why the presiding officer may not pronounce judgment of removal as a necessary consequence of conviction, but the custom of the senate is against it. A formal vote was taken in the cases of both Pickering and Humphreys. In the first case Judge Pickering was condemned by a vote of 19 to 7 . The vote to remove from office was 20 to $6 .^{34}$ On two of the articles against Judge Humphreys the vote stood 39 to 0 ; on one, 28 to 10 . On motion to add disqualification to hold office to the penalty of removal the result was 27 to 10 . The presiding officer ruled that the question was still divisible and put each part separately. On the question of removal the result was 38 to 0 ; on that of disqualification, 36 to $0 .^{35}$ In the course of the Johnson trial a resolution was offered by Mr. Sumner, the implacable enemy of the president, declaring that the requirement of a two-thirds majority did not extend to disqualification, but it never came to a vote ${ }^{36}$

The question as to whether an impeachment trial is terminated by a dissolution of congress has never been raised in a practical way. In 1679 the lords determined that an impeachment was not terminated by a dissolution of parliament. This decision was reversed in the case of Danby in 1685, four parliaments having dissolved without bringing the accusation to an issue. The question was raised again in the trial of Warren Hastings. After able arguments on both sides the decision

\footnotetext{
${ }^{33}$ State v. Hastings, 37 Neb. Rep., 96.

${ }^{34}$ Ann. 8 Cong., 1 Sess., 367.

${ }^{35}$ Extracts from Journals of Senate, etc., $183 \mathrm{ff}$.

${ }^{36}$ Johnson Trial, 331, 410.
} 
of 1685 was reversed by large majorities in both houses and the decision of 1679 was declared to be the law of the land. ${ }^{37}$

This last decision was made in 1791. Did we in our Constitution of 1787 adopt the rule of 1685? Subsequent changes in the English law can have no effect on our own. It has already been stated that we adopted the English law of impeachment as it existed in 1787, with a few changes. Although no mention was made of this particular point, the writer is not inclined to believe that impeachments are to be regarded as terminated by a dissolution. In the first place it is doubtful if the decision of 1685 ever really was the law in England. In the second, the analogy between impeachments and bills does not hold. It was argued that all bills fail by a dissolution and must be introduced de novo in the next house. But an impeachment is not a bill, neither is a court of impeachment a legislative body. Cases are not thrown out of our courts even by a change of judge and jury, much less by a change of prosecuting attorneys. The senate sitting as a court of impeachment is a court of record; the senate may be called a permanent body. Only the prosecutor, the house, changes by a dissolution. What need is there, then, for it to begin an impeachment de novo?

The question whether an offense to be impeachable must also be indictable was raised by Judge Chase in his trial and the affirmative side was ably argued by his counsel, one of whom, Luther Martin, had sat in the convention of 1787 , but had gone home in disgust without signing the Constitution. It does not appear to have been raised in the Blount and Pickering trials, but it was raised in that of Judge Addison, an officer of the State of Pennsylvania in 1802-03. In his defense the judge held that "an impeachment lies only where an indictment lies," and seems to have relied mainly upon the fact that removal by address was provided for in cases where there was not sufficient ground for impeachment. But he was convicted by a vote of 20 to 4 . This case was cited at length by Mr. Rodney, one of the managers in the Chase trial, who was ably supported by Mr. Nicholson in holding that an offense to be impeachable need not be indictable. Mr. Harper one of the counsel for Chase, practically abandoned the contention of

${ }^{37}$ Hallam, Constitutional History of England, ii, 173-177. 
his client. ${ }^{38}$ Judge Chase was acquitted, but there is no evidence that the senators thought his contention in this matter correct. Judge Peck seems to have conceded that one might be impeached for crimes not indictable, but held that the act must be wilfully and knowingly done in violation of law" with malicious intention. ${ }^{30}$ It is doubtful if more than one of the crimes charged against Judge Humphreys was indictable. In the Johnson trial the defense did not claim that only indictable offenses were impeachable, but the managers argued the negative side at length ${ }^{40}$ As Belknap was already under indictment at the time of his trial there was no need to discuss the question. The counsel for Judge Swayne took about the same ground as did Judge Peck. They also asserted that some crimes, both in England and America, were indictable which were not impeachable and that for these the remedy was to be found in a regular court of justice. ${ }^{41}$ This is undoubtedly true in America, but one may assert with equal positiveness that it was not true in England, where anything was impeachable which parliament so regarded.

While the Constitution names the crimes for which one may be impeached, the senate sitting as a court of impeachment is the sole judge of what offenses fall within the category of "treason, bribery, or other high crimes and misdemeanors." Treason is defined in the Constitution and that definition cannot be enlarged upon. Bribery is a term upon the meaning of which there is supposed to be substantial agreement, yet this is capable of enlargement by constructive interpretation according to the contention of the managers in the Johnson trial, who held that the president's promise to General Thomas to assume responsibility for violation of the tenure-of-office act was bribery. But "high crimes and misdemeanors" is more open to interpretation than either of the others. It rests with the senate alone to say what are impeàchable high crimes and misdemeanors. They must do this according to the common law and parliamentary practice, but of these they are the sole judges. From their decision there is no appeal.

The question naturally arises here as to what majority is necessary

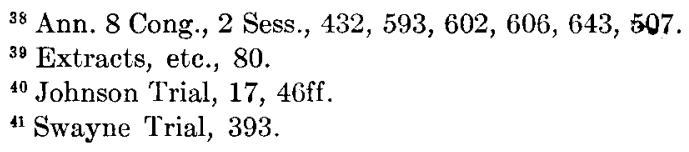

${ }^{41}$ Swayne Trial, 393. 
to determine whether the crime charged falls within the category of impeachable offenses. The matter has never been presented to the senate in just this form. An analogous question was that of jurisdiction in the Belknap trial, which has already been discussed at length. To the layman it looks as if the question ought to have been raised in the Swayne trial. The judge was charged with high crimes and misdemeanors in obtaining money from the United States by a false pretense, using without compensation the property of a railroad which was in the hands of a receiver appointed by himself, not residing within his district as required by law, and maliciously and unlawfully fining for contempt of court. The defense maintained that even if true, the allegations did not constitute an impeachable offense. ${ }^{12}$ There seems to have been very little doubt that the accused was guilty of some of the things charged, but he was acquitted. The impression of the public seems to have been that the judge was acquitted because the senate did not think that his peccadilloes amounted to impeachable high crimes and misdemeanors. The proper course, then, would have been for the defense to have entered a demurrer and called for a ruling on the impeachability of the crimes charged. If not sustained, the case could then have been tried on its merits. Even if a two-thirds majority were required to settle such a question, the time and expense of a trial might be saved by settling it in advance.

The framers of the Constitution wisely provided that in the trial of the president the chief justice should preside, because the vice-president would be interested in the result. It probably never occurred to them that any senator might be immediately affected by the result, but such was the case in the Johnson trial. At that time the president pro tempore of the senate would have succeeded to the presidency in case of a vacancy. Senator Wade held this position at the time. No written law forbade him to participate in the trial, neither was he deterred by the law of delicacy from taking an active part and exultingly recording his vote for condemnation, a vote which, with one change, would have seated him in the presidency. Soon after the opening of the trial Mr. Sumner offered a resolution to the effect that the chief justice had no right to vote on any question during the trial.

${ }^{42}$ Swayne Trial, 393f. 
After this was negatived by a vote of 22 to 26,6 not voting, Mr. Drake offered one to the effect that he had no privilege of ruling on questions of law, but that all such should be submitted to the decision of the senate alone. This was negatived by a vote of 20 to 30,4 not voting, ${ }^{43}$ from which it seems clear that the chief justice succeeds to all the rights and privileges of the vice-president.

${ }^{43}$ Johnson Trial, 63. 